\title{
Synthesis, Characterization, and Photocatalytic Activity of ZnO Nanomaterials Prepared by a Green, Nonchemical Route
}

\author{
Ngoc Thinh Nguyen (iD) ${ }^{1}$ and Van Anh Nguyen $\mathbb{D D}^{2}$ \\ ${ }^{1}$ School of Chemical Engineering, Hanoi University of Science and Technology, Hanoi 100000, Vietnam \\ ${ }^{2}$ Faculty of Natural Sciences and Technology, Hanoi Metropolitan University, Hanoi 100000, Vietnam \\ Correspondence should be addressed to Ngoc Thinh Nguyen; thinh.nguyenngoc@hust.edu.vn
}

Received 18 June 2020; Revised 7 September 2020; Accepted 15 September 2020; Published 1 October 2020

Academic Editor: Changfa Guo

Copyright (c) 2020 Ngoc Thinh Nguyen and Van Anh Nguyen. This is an open access article distributed under the Creative Commons Attribution License, which permits unrestricted use, distribution, and reproduction in any medium, provided the original work is properly cited.

\begin{abstract}
An eco-friendly method for the synthesis of $\mathrm{ZnO}$ nanoparticles was studied. Zinc acetate precursor was thermally decomposed without adding any chemical agents. The synthesized materials were thoroughly characterized by various analytical tools. The results indicated that the synthesized $\mathrm{ZnO}$ nanomaterials have a wurtzite structure. The estimated crystallite sizes of the materials obtained at $450,550,650$, and $750^{\circ} \mathrm{C}$ (named as $\mathrm{ZnO}-450, \mathrm{ZnO}-550, \mathrm{ZnO}-650$, and $\mathrm{ZnO}-750$ ) were 33, 36, 38, and $42 \mathrm{~nm}$, respectively. The morphology of the nanomaterials was revealed to be affected by calcination temperature, causing the formation of both nanoparticles and nanorods with different sizes and shapes. The materials were applied as photocatalysts for methylene blue $(\mathrm{MB})$ decomposition under ultraviolet (UV) light. Results showed that the decomposition efficiency strongly depends on UV illumination time, size, and morphology of $\mathrm{ZnO}$ nanomaterials. The highest $\mathrm{MB}$ decomposition (99.4\%) is obtained when using $\mathrm{ZnO}-750$. The photocatalytic decomposition follows the first-order reaction. The reaction rate constants corresponding to the $\mathrm{MB}$ decomposition process with the presence of $\mathrm{ZnO}-450$, $\mathrm{ZnO}-550$, $\mathrm{ZnO}-650$, and $\mathrm{ZnO}-750$ are 0.0512 , $0.0636,0.1077$, and $0.1286 \mathrm{~min}^{-1}$, respectively.
\end{abstract}

\section{Introduction}

Textile industry annually generates a huge amount of organic dyes, resulting in serious impacts on the environment. Therefore, the removal of organic dyes from textile wastewater is considered an essential need. Numerous different technologies have been applied to remove organic dyes in wastewater such as adsorption, coprecipitation, advanced oxidation process (AOP), ozonation, membrane filtration, and biological methods $[1,2]$. AOP is noticeable because it could quickly remove various types of dyes. Among AOP techniques, the technique using heterogeneous photocatalytic catalyst is gaining attention as it can remove not only organic dyes but also other organic pollutants [1-5].

It is widely known that $\mathrm{ZnO}$ is a semiconductor with broad band gap energy $(3.3 \mathrm{eV})$ and n-type conductivity. In addition, it is very common in nature and environmentally friendly. That is the reason why $\mathrm{ZnO}$ is considered a very promising material for different applications such as making solar cells, photocatalysts, electrical equipment, and gas sensors [4]. In the recent years, researchers have focused on synthesizing nano-size $\mathrm{ZnO}$ materials for dye removal. $\mathrm{ZnO}$ nanomaterials can be synthesized by different methods including the sol-gel method [6], microwave method [7, 8], hydrothermal method $[9,10]$, precipitation method [11, 12], and thermal decomposition method [13-18]. Among these, thermal decomposition method is considering as an approach to "green method" that does not consume and/or generate toxic chemicals and/or solvents. Moreover, the method allows to prepare a huge amount of sample at one batch [13]. On the attempt to minimize generating toxic wastes, this study synthesized $\mathrm{ZnO}$ nanoparticles by thermal decomposition of zinc acetate. The materials were characterized and tested for photocatalytic activity. 


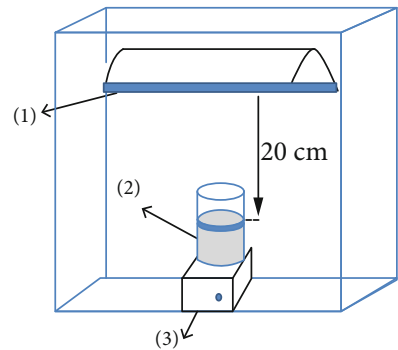

FIgure 1: Photoreactor (1): high-pressure mercury lamp; (2): Pyrex glass beaker; (3): magnetic stirring.

\section{Materials and Methods}

2.1. Synthesis of $\mathrm{ZnO}$ Nanomaterials. The analytical grade zinc acetate dihydrate $\left(\mathrm{Zn}(\mathrm{Ac})_{2} \cdot 2 \mathrm{H}_{2} \mathrm{O}\right)$ was purchased from $\mathrm{BDH}$ (England) and directly used without further purification. The $\mathrm{ZnO}$ nanoparticles were prepared by thermal decomposition method $[15,16]$, with several modifications. The amount of $3 \mathrm{~g}$ zinc acetate dihydrate $\left(\mathrm{Zn}(\mathrm{Ac})_{2} \cdot 2 \mathrm{H}_{2} \mathrm{O}\right)$ was grinded in an agate mortar. The samples were then transferred to closed porcelain crucibles and left in an oven (Nabertherm, Germany) for thermal decomposition at $450^{\circ} \mathrm{C}, 550^{\circ} \mathrm{C}, 650^{\circ} \mathrm{C}$, and $750^{\circ} \mathrm{C}$ within 4 hours with the temperature increasing rate of $10^{\circ} \mathrm{C} / \mathrm{min}$. The samples were allowed to cool down to room temperature and ground in the agate mortar to obtain final $\mathrm{ZnO}$ nanoparticles. Obtained products were named as $\mathrm{ZnO}-450, \mathrm{ZnO}-550, \mathrm{ZnO}-650$, and $\mathrm{ZnO}-750$ in accordance with the calcination temperatures of the samples.

2.2. Characterization Methods. The X-ray powder diffraction (XRD) patterns of the synthesized nanoparticles were provided using a Bruker D8 advanced X-ray diffractometer equipped with graphite monochromatized $\mathrm{Cu} \mathrm{K} \alpha$ radiation ( $\lambda=1.5418 \AA)$, scanning rate of $0.02 \mathrm{~s}^{-1}$ and scanning range of $20-75^{\circ}$. The field emission scanning electron microscopy (FESEM) characterization was performed on Hitachi S4800 at $15 \mathrm{kV}$. Transmission electron microscopy (TEM) images were obtained with a JEOL JEM-1010 transmission electron microscope operating at an acceleration voltage of $200 \mathrm{kV}$. The thermal decomposition of zinc acetate dihydrate was studied by thermal gravimetric analysis (TGA) (DSC131, LABSYS TG/DSC1600, TMA, and Setaram, France) to determine its thermal stability and decomposition temperature. The thermogravimetry (TG) curve of zinc acetate dihydrate was recorded in an air flow at the heating rate of $10^{\circ} \mathrm{C} / \mathrm{min}$ from room temperature to $900^{\circ} \mathrm{C}$. The nitrogen adsorptiondesorption isotherms of the $\mathrm{ZnO}$ nanomaterials were recorded by the TriStar II 3020 nitrogen adsorption apparatus (Micromeritics Instruments, USA) at $77 \mathrm{~K}$. The BET specific surface areas $\left(S_{\mathrm{BET}}\right)$ of the samples were determined by the Barrett-Joyner-Halenda (BJH) method.

2.3. Photocatalytic Study. The potential application of $\mathrm{ZnO}$ nanoparticles towards dye removal from wastewaters was evaluated in heterogeneous photocatalysis route. Methylene

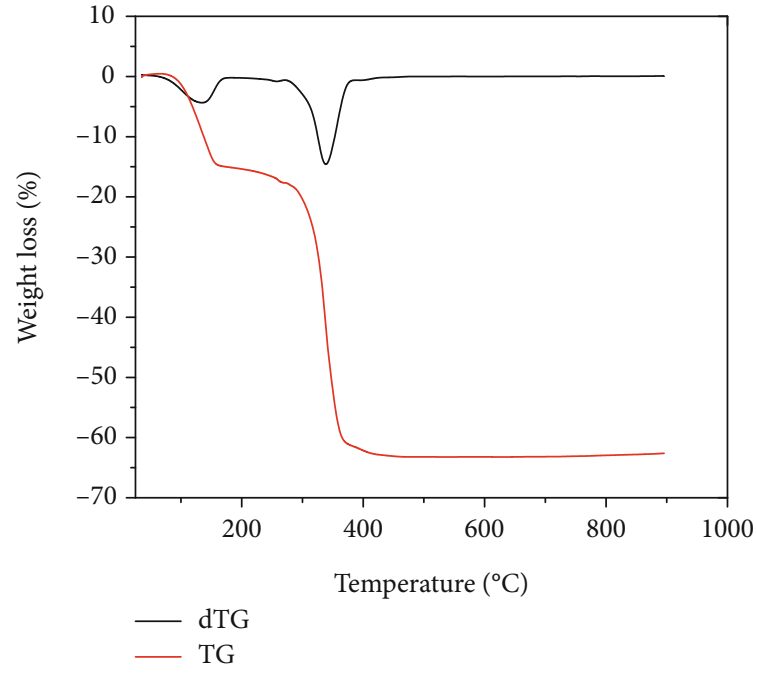

FIGURE 2: TG-DTG curve of thermal decomposition of zinc acetate dihydrate at heating rate of $10^{\circ} \mathrm{C}$ in air.

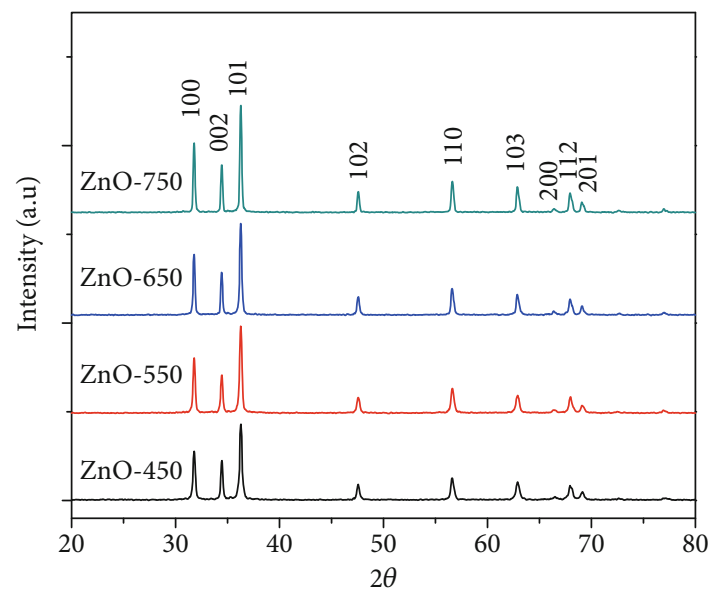

FIGURE 3: XRD patterns of the nanocrystalline $\mathrm{ZnO}$ samples thermally decomposed at $450,550,650$, and $750^{\circ} \mathrm{C}$ for $4 \mathrm{~h}$.

blue $(\mathrm{MB})$ was used to test the photocatalytic efficiency of the $\mathrm{ZnO}$ nanoparticles. Photocatalytic reaction was carried out in a homemade photoreactor equipped with an Osram $250 \mathrm{~W}$, high-pressure mercury lamp as a source for UV radiation (Figure 1). The reactor consists of a Pyrex glass beaker and a magnetic stirring. The lamp is positioned above the beaker. The distance between the lamp and the Pyrex glass beaker is $20 \mathrm{~cm}$. The whole photocatalytic reactor is insulated in a box to prevent harmful radiation. For every batch experiment, $0.1 \mathrm{~g}$ of $\mathrm{ZnO}$ nanoparticles was dispersed in $100 \mathrm{~mL}$ aqueous solution of MB $10 \mathrm{mg} / \mathrm{L}$. Prior to UV light illumination, the suspension was magnetically stirred in the dark for $30 \mathrm{~min}$ in order to obtain proper homogeneity of the mixture as well as to reach the absorption equilibrium. At definite time intervals, $4 \mathrm{~mL}$ of the mixture was collected and followed by centrifugation (Hettich Mikro 22R Centrifuges), at $5000 \mathrm{rpm}$ for $10 \mathrm{~min}$ to remove the $\mathrm{ZnO}$ nanoparticles 
TABLE 1: Comparison between XRD results of $\mathrm{ZnO}$ nanoparticles and standard pattern for $\mathrm{ZnO}$ powder.

\begin{tabular}{ccccccccccccccc}
\hline \multicolumn{3}{c}{ JCPDS (36-1451) } & \multicolumn{3}{c}{ ZnO-450 } & \multicolumn{3}{c}{ ZnO-550 } & \multicolumn{3}{c}{ ZnO-650 } & \multicolumn{2}{c}{ ZnO-750 } \\
$h k l$ & $2 \theta$ & $\% \mathrm{I}$ & $2 \theta$ & \%I & FWHM & $2 \theta$ & $\% \mathrm{I}$ & FWHM & $2 \theta$ & \%I & FWHM & $2 \theta$ & $\% \mathrm{I}$ & FWHM \\
\hline 100 & 31.76 & 57 & 31.79 & 64 & 0.236 & 31.79 & 63 & 0.236 & 31.79 & 66 & 0.207 & 31.79 & 64 & 0.207 \\
002 & 34.42 & 44 & 34.46 & 51 & 0.207 & 34.47 & 43 & 0.207 & 34.43 & 46 & 0.236 & 34.43 & 44 & 0.207 \\
101 & 36.25 & 100 & 36.28 & 100 & 0.266 & 36.27 & 100 & 0.246 & 36.26 & 100 & 0.230 & 36.26 & 100 & 0.207 \\
102 & 47.53 & 23 & 47.56 & 20 & 0.266 & 47.54 & 17 & 0.325 & 47.59 & 20 & 0.236 & 47.59 & 19 & 0.236 \\
110 & 56.60 & 32 & 56.58 & 28 & 0.236 & 56.62 & 28 & 0.325 & 56.55 & 27 & 0.207 & 56.55 & 27 & 0.295 \\
103 & 62.86 & 29 & 62.87 & 22 & 0.354 & 62.78 & 16 & 0.236 & 62.83 & 21 & 0.266 & 62.83 & 20 & 0.207 \\
112 & 67.96 & 22 & 67.94 & 17 & 0.413 & 67.99 & 18 & 0.207 & 67.93 & 17 & 0.413 & 67.91 & 17 & 0.354 \\
201 & 69.09 & 16 & 69.14 & 10 & 0.360 & 69.10 & 9 & 0.413 & 69.08 & 9 & 0.236 & 69.05 & 9 & 0.207 \\
\hline
\end{tabular}

TABLE 2: Estimated structure parameters and average crystallite size of $\mathrm{ZnO}$ nanoparticles from the XRD data.

\begin{tabular}{lccccc}
\hline Samples & $a(\AA)$ & $c(\AA)$ & $c / a$ & $\begin{array}{c}\text { Volume of } \\
\text { unit cell } \\
\left(\AA^{3}\right)\end{array}$ & $\begin{array}{c}\text { Size of the } \\
\text { crystallites } \\
(\mathrm{nm})\end{array}$ \\
\hline JCPDS 36-1451 & 3.249 & 5.205 & 1.602 & 47.58 & $\mathrm{x}$ \\
$\mathrm{ZnO}-450$ & 3.246 & 5.199 & 1.602 & 47.44 & 33 \\
$\mathrm{ZnO}-550$ & 3.246 & 5.198 & 1.601 & 47.43 & 36 \\
$\mathrm{ZnO}-650$ & 3.246 & 5.203 & 1.603 & 47.48 & 38 \\
$\mathrm{ZnO}-750$ & 3.246 & 5.203 & 1.603 & 47.48 & 42 \\
\hline
\end{tabular}

suspensions from the solution. Samples were finally analyzed by Agilent $8453 \mathrm{UV}$-vis spectrophotometer at the $\lambda_{\max }$ of $664 \mathrm{~nm}$ wavelength. The percentage of photocatalytic degradation was calculated using the following equation:

$$
\text { Percentage photodegardation }=\frac{A_{0}-A}{A_{0}} \times 100 \text {. }
$$

The rate constant of the degradation, $k$, was obtained from the first-order plot according to the equation: $\ln \left(A_{0}\right)$ $A)=k t$, where $A_{0}$ is the initial absorbance of dye and $A$ is the absorbance of dye solution after UV light irradiation [19].

\section{Results and Discussion}

3.1. Characterization of $\mathrm{ZnO}$ Nanoparticles. The TG and dTG (differential thermogravimetric) curves are provided in Figure 2. The two-stage weight loss was observed. The first stage with approximately $15.72 \%$ of weight loss was presumed to be the thermal dehydration of zinc acetate dihydrate to form anhydrous zinc acetate. The second stage (47.58\% of weight loss) within the temperature region from 250 to $350^{\circ} \mathrm{C}$ is accounted for the decomposition of anhydrous zinc acetate to form $\mathrm{ZnO}$ [15]. The weight loss was no longer observed within the temperature ranges from 350 to $900^{\circ} \mathrm{C}$. This signaled the complete decomposition of the precursor at $350^{\circ} \mathrm{C}$. Therefore, the calcination temperatures of $450^{\circ} \mathrm{C}, 550^{\circ} \mathrm{C}, 650^{\circ} \mathrm{C}$, and $750^{\circ} \mathrm{C}$ were selected.

The XRD patterns of the prepared products are shown in Figure 3. The major XRD peaks locate at angles $(2 \theta)$ of $31.8^{\circ}$, $34.4^{\circ}, 36.2^{\circ}, 47.5^{\circ}, 56.6^{\circ}, 62.8^{\circ}, 66.3^{\circ}, 68.1^{\circ}$, and $69.3^{\circ}$ corresponding to the (100), (002), (101), (102), (110), (103), (200), (112), and (201) planes of $\mathrm{ZnO}$, respectively. The standard diffraction peaks show the hexagonal wurtzite structure of $\mathrm{ZnO}$ with $\mathrm{P} 63 \mathrm{mc}$ space group $[10,20]$. None of the peaks for impurities was observed. Furthermore, strong intensity and narrow width of $\mathrm{ZnO}$ diffraction peaks suggest that the dominant phase of the product is hexagonal wurtzite structure $[5,10-12]$. The X'Pert High Score was used to further interpret the XRD patterns. The characteristic peaks of the synthesized nanoparticles are completely identical to those from the JCPDS data (Card No. 36-1451) (Table 1) [20]. The crystallite size of the nanoparticles was calculated from the peak broadening of diffraction peaks using the DebyeScherer formula $D=k \lambda / \beta \cos \theta$, where $D$ is crystallite size, $k$ is constant (0.89), $\lambda=0.154 \mathrm{~nm}$ represents the wavelength of $\mathrm{X}$-ray radiation, $\beta$ is the full width at half maximum of diffraction peaks (FWHM) in radian, and $\theta$ is Bragg's angle [12]. The size of the crystallites of $\mathrm{ZnO}$ nanoparticles was evaluated by measuring the FWHM of the most intense peak (101). Approximately, the average crystallite size of $\mathrm{ZnO}-450$ is $33 \mathrm{~nm}$ while those of $\mathrm{ZnO}-550, \mathrm{ZnO}-650$, and $\mathrm{ZnO}-750$ are 36,38 , and $42 \mathrm{~nm}$, respectively. The elevated surface energies at higher calcination temperatures may be responsible for the increasing of the crystallite size. Similar phenomenon was also reported in former studies [16].

The lattice cell parameters ( $a$ and $c$ ) of hexagonal wurtzite structure were calculated as follows [12]:

$$
\begin{aligned}
c & =\frac{\lambda}{\sin \theta_{(002)}}, \\
a & =\frac{\lambda}{\sqrt{3} \sin \theta_{(100)}}, \\
\frac{1}{d_{h k l}^{2}} & =\frac{4}{3}\left[\frac{h^{2}+h k+k^{2}}{a^{2}}\right]+\frac{l^{2}}{c^{2}},
\end{aligned}
$$

where $d$ is the interplanar distance; $h, k$, and $l$ are the Miller indices of the plane; $\lambda=1.54 \AA$ is the wavelength of the $\mathrm{X}$ rays; and $\theta_{100}$ and $\theta_{002}$ are angles of the diffraction in degree corresponding to the planes 100 and 002 . The volume $(V)$ of 

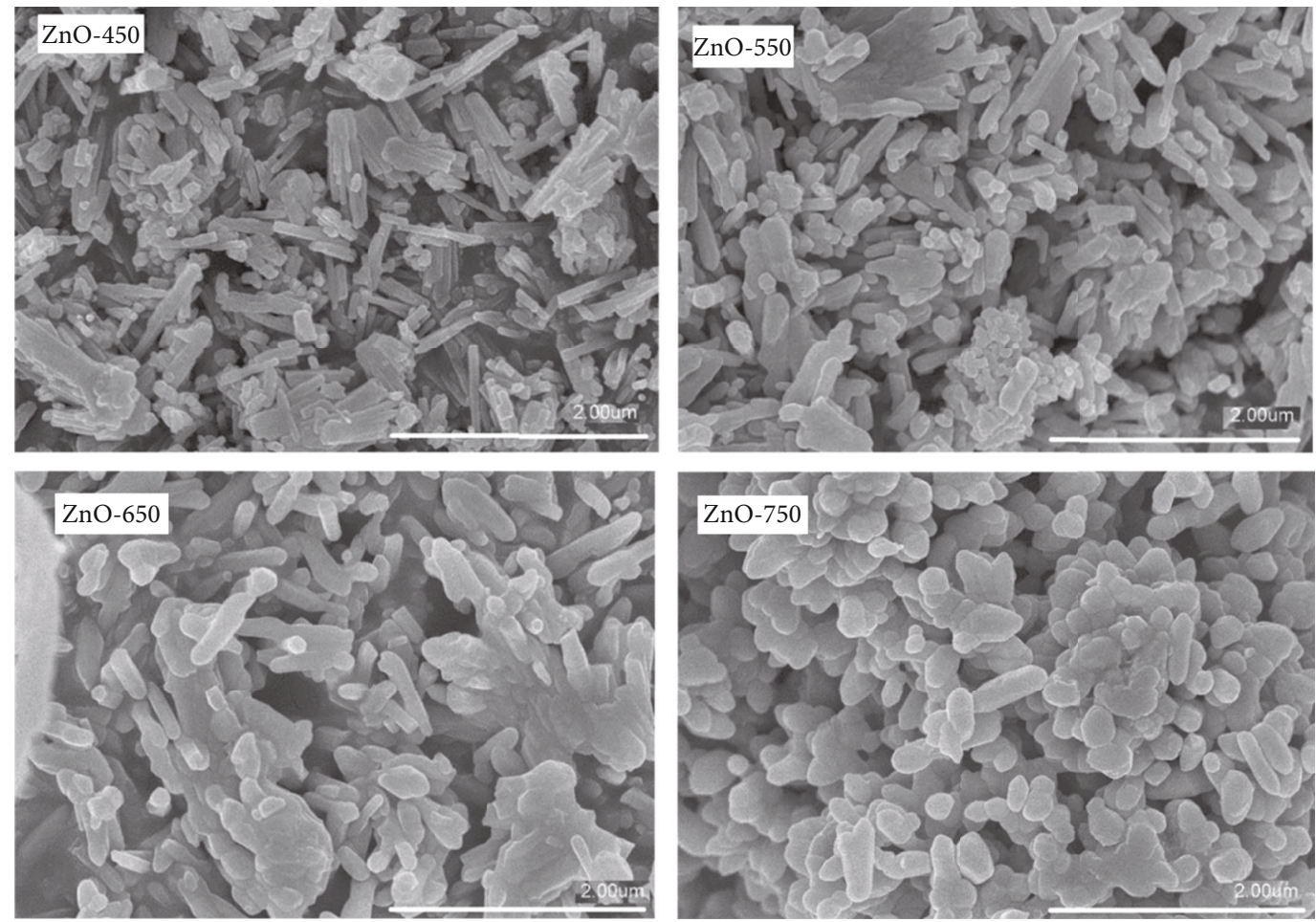

FIgURE 4: FESEM images of the $\mathrm{ZnO}$ nanoparticles thermally decomposed at $450,550,650$, and $750^{\circ} \mathrm{C}$.

the unit cells of hexagonal wurtzite structure was calculated in the following equation:

$$
V=0.866 \times a^{2} \times c .
$$

Results are listed in Table 2. It was evident that the lattice parameter values of as-synthesized $\mathrm{ZnO}$ nanoparticles are similar to the standard values of $\mathrm{ZnO}$.

The surface morphology and size of $\mathrm{ZnO}$ nanoparticles were imaged using the FESEM analysis (Figure 4). Both sphere-like (diameters of $40-100 \mathrm{~nm}$ ) and rod-like (diameters of 50-200 nm and lengths of 200-500 nm) ZnO nanoparticles were observed. Calcination temperatures seem to dramatically affect the morphology of the nanoparticles. At the temperature of $450^{\circ} \mathrm{C}$, the rod-like particles are predominant. Nevertheless, more sphere-like particles are formed as increasing the temperatures. This is also confirmed by the transmission electron microscopic (TEM) analysis (Figure 5).

BET surface areas of $\mathrm{ZnO}-450, \mathrm{ZnO}-550, \mathrm{ZnO}-650$, and $\mathrm{ZnO}-750$ are $6.8,4.8,3.3$, and $2.4\left(\mathrm{~m}^{2} / \mathrm{g}\right)$, respectively (Table 3). The surface area of $\mathrm{ZnO}$ nanoparticles decreases when increasing the calcination temperature.

3.2. Photocatalytic Properties. Figure 6 shows the absorption spectra of the degradation of $\mathrm{MB}$ under UV light with the presence of $\mathrm{ZnO}$ nanoparticles. Decrease in absorbance intensity at $664 \mathrm{~nm}$ clearly confirms that $\mathrm{ZnO}$ nanoparticles are acting as photocatalyst for the degradation of dye.

The $\mathrm{ZnO}$ nanoparticles synthesized at higher temperatures tend to yield higher removal efficiencies. Figure 7 shows that the best degradation efficiency can be achieved with the
$\mathrm{ZnO}-650$ and $\mathrm{ZnO}-750$ (approximately $100 \%$ within $40 \mathrm{~min}$ ). It is widely known that morphology, surface area, and crystallinity of a material are mainly responsible for its photocatalytic activity $[21,22]$. When enhancing the surface area and crystallinity of the material, the photocatalytic activity will be improved. Nevertheless, while the crystallinity of the material increases, the surface area of the material decreases as raising calcination temperature (Figure 3 and Table 3). Therefore, morphology could act as a potential factor strongly influencing the final degradation efficiency. According to the results sphere-shaped $\mathrm{ZnO}$ nanoparticles ( $\mathrm{ZnO}-650$ and $\mathrm{ZnO}-750$ ) show higher removal efficiency compared with the spindle-and rod-shaped $\mathrm{ZnO}$ nanoparticles (ZnO-450 and $\mathrm{ZnO}-550)$. Similar results were observed in Saravanan et al. [23].

The kinetic study for the degradation of $\mathrm{MB}$ was studied using the Langmuir-Hinshelwood kinetic model: $\ln \left(A_{0} / A\right)$ $=k t$, where $A_{0}$ is initial absorbance of dye, $A$ is absorbance of dye solution after UV light irradiation, and $k$ is a pseudofirst-order rate constant [19]. A plot of $\ln \left(A_{0} / A\right)$ versus $t$ is shown in Figure 8. Photocatalytic activity occurs because of the interaction of photocatalyst and UV irradiation that yields highly reactive hydroxyl radicals, which are believed to be the main species responsible for the oxidation. Other active species such as holes, free electrons, and superoxide could also act as oxidant species for the degradation of $\mathrm{MB}$. The reaction process was proposed elsewhere in Qi et al. and numerous former studies [4, 19, 24, 25]. The Langmuir-Hinshelwood rate expression has been successfully used for heterogeneous photocatalytic degradation to determine the relationship between the initial degradation rate and the initial concentration of the organic substrate $[1,9]$. 

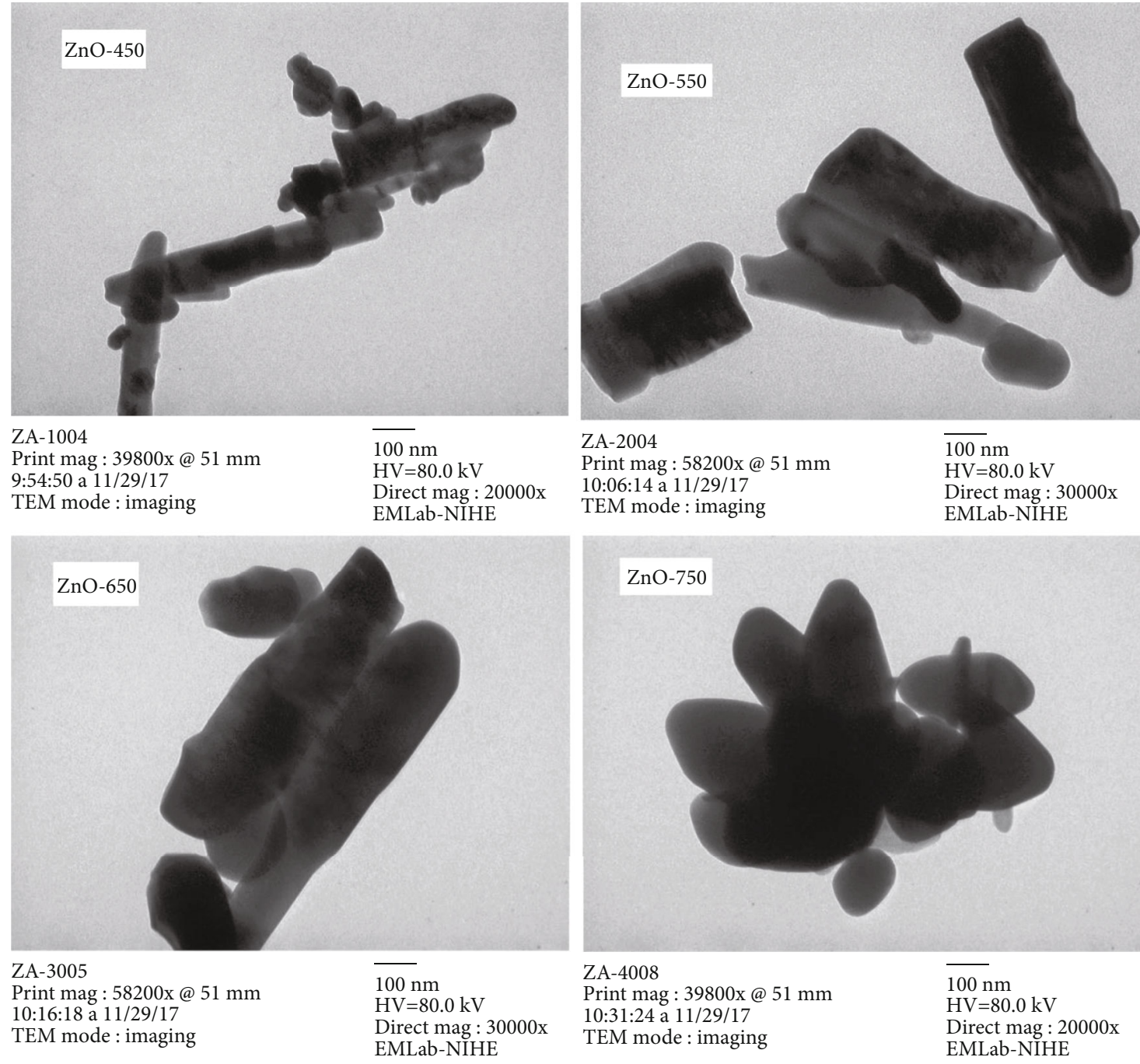

Figure 5: TEM images of the $\mathrm{ZnO}$ nanoparticles thermally decomposed at $450,550,650$, and $750^{\circ} \mathrm{C}$.

TABLE 3: BET surface areas of $\mathrm{ZnO}$ nanoparticles thermally decomposed at $450,550,650$, and $750^{\circ} \mathrm{C}$.

\begin{tabular}{lc}
\hline Sample & $S_{\mathrm{BET}}\left(\mathrm{m}^{2} / \mathrm{g}\right)^{\mathrm{a}}$ \\
\hline $\mathrm{ZnO}-450$ & 6.8 \\
$\mathrm{ZnO}-550$ & 4.8 \\
$\mathrm{ZnO}-650$ & 3.3 \\
$\mathrm{ZnO}-750$ & 2.4 \\
\hline
\end{tabular}

${ }^{\mathrm{a} B E T}$ surface area calculated from the linear part of the BET plot.

The linear plots and relatively high $R^{2}$ values (Table 4 ) prove that the degradation of MB obeys the first-order reaction kinetics.

The removal efficiency of the synthesized $\mathrm{ZnO}$ nanoparticles was comparable with other materials in former studies (Table 5). It can be concluded that the obtained materials have high potential to be applied for organic dye removal.

Stability and reusability of $\mathrm{ZnO}-750$ were tested. Results show that the removal efficiency negligible decreases from
99.4\% to $94.1 \%$ at the third cycle (Figure 9). This suggests the good reuse performance of the material $[29,30]$.

\section{Conclusions}

$\mathrm{ZnO}$ nanomaterials were successfully generated by a green method, thermal decomposition of zinc acetate precursor at $450,550,650$, and $750^{\circ} \mathrm{C}$. Results reveals a wurtzite hexagonal structure of $\mathrm{ZnO}-450, \mathrm{ZnO}-550, \mathrm{ZnO}-650$, and $\mathrm{ZnO}-750$ with the crystal sizes of $33,36,38$, and $42 \mathrm{~nm}$, respectively. The material morphology changes from the rod-like shapes to the sphere-like shapes when increasing decomposition temperature.

$\mathrm{ZnO}$ nanomaterials were applied as photocatalyst to decompose MB under UV light. The ability to decompose $\mathrm{MB}$ depends on the UV illumination time, the size, and morphology of $\mathrm{ZnO}$ nanomaterials. The highest $\mathrm{MB}$ decomposition is obtained with the $\mathrm{ZnO}-750$. More than $99 \%$ of the dye was removed after 40 minutes. Photocatalytic decomposition process of methylene blue follows the first-order reaction. The reaction rate constants corresponding to the removal 

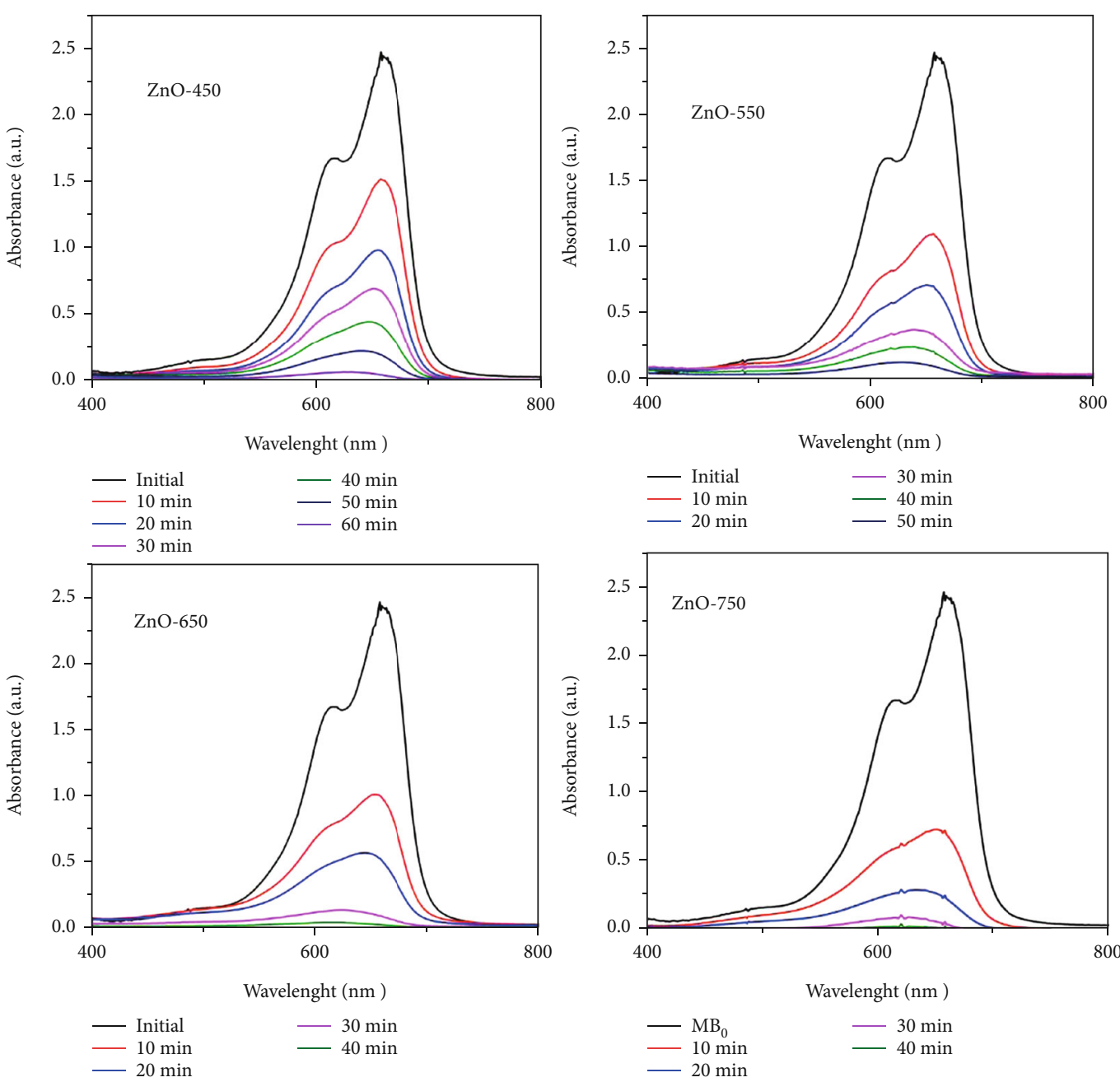

Figure 6: UV-vis absorbance spectra of MB solution exposure to UV light in the presence of the ZnO nanoparticles thermally decomposed at $450,550,650$, and $750^{\circ} \mathrm{C}$.

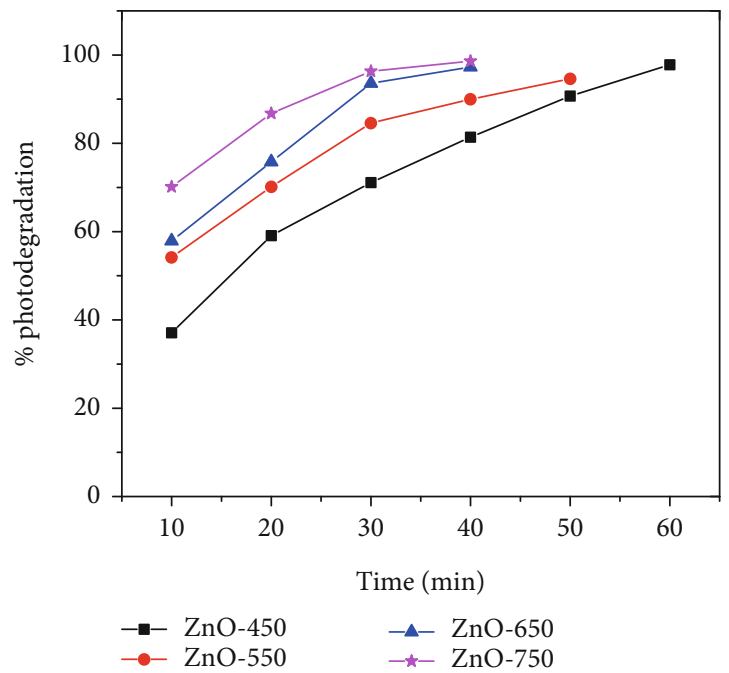

Figure 7: Percentage degradation of methylene blue dye vs. irradiation time in the presence of the $\mathrm{ZnO}$ nanoparticles thermally decomposed at $450,550,650$, and $750^{\circ} \mathrm{C}$.

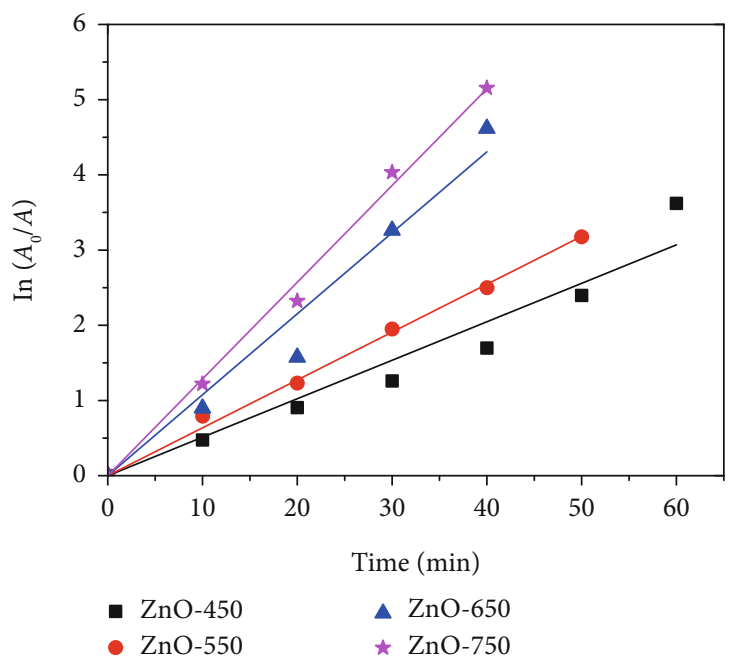

Figure 8: Kinetic plot of $\ln \left(A_{0} / A\right)$ vs. irradiation time of the $\mathrm{ZnO}$ nanoparticles thermally decomposed at $450,550,650$, and $750^{\circ} \mathrm{C}$. 
TABLE 4: Rate constant for photo degradation of methylene blue dye.

\begin{tabular}{lcc}
\hline Samples & Rare $\left(\mathrm{min}^{-1}\right)$ & Adj. $R^{2}$ \\
\hline $\mathrm{ZnO}-450$ & 0.0512 & 0.9740 \\
$\mathrm{ZnO}-550$ & 0.0636 & 0.9984 \\
$\mathrm{ZnO}-650$ & 0.1077 & 0.9835 \\
$\mathrm{ZnO}-750$ & 0.1286 & 0.9990 \\
\hline
\end{tabular}

TABLE 5: Photocatalytic degradation of methylene blue with different $\mathrm{ZnO}$ nanomaterials under UV light catalyst methods.

\begin{tabular}{|c|c|c|c|c|}
\hline Catalyst & Methods & \%removal & $\begin{array}{l}\text { Degradation } \\
\text { rate }\left(\mathrm{min}^{-1}\right)\end{array}$ & Ref \\
\hline \multirow{3}{*}{ Nanosized ZnO } & Sol-gel & 99 & - & [23] \\
\hline & Precipitation & 98 & - & [23] \\
\hline & $\begin{array}{c}\text { Thermal } \\
\text { decomposition }\end{array}$ & 85 & - & [23] \\
\hline $\begin{array}{l}\mathrm{ZnO} \\
\text { nanoparticles }\end{array}$ & Precipitation & 92.5 & 0.0124 & {$[26]$} \\
\hline $\begin{array}{l}\mathrm{ZnO} \\
\text { nanospheres }\end{array}$ & Polyol-method & 99.1 & 0.07432 & [27] \\
\hline $\begin{array}{l}\text { Nitrogen doped } \\
\mathrm{ZnO} \\
\text { nanoparticles }\end{array}$ & $\begin{array}{l}\text { Hydrothermal } \\
\text { method }\end{array}$ & 99.6 & -0.0579 & {$[28]$} \\
\hline $\begin{array}{l}\mathrm{ZnO} \\
\text { nanoparticles }\end{array}$ & $\begin{array}{c}\text { Thermal } \\
\text { decomposition }\end{array}$ & 99.4 & 0.1286 & $\begin{array}{l}\text { This } \\
\text { study }\end{array}$ \\
\hline
\end{tabular}

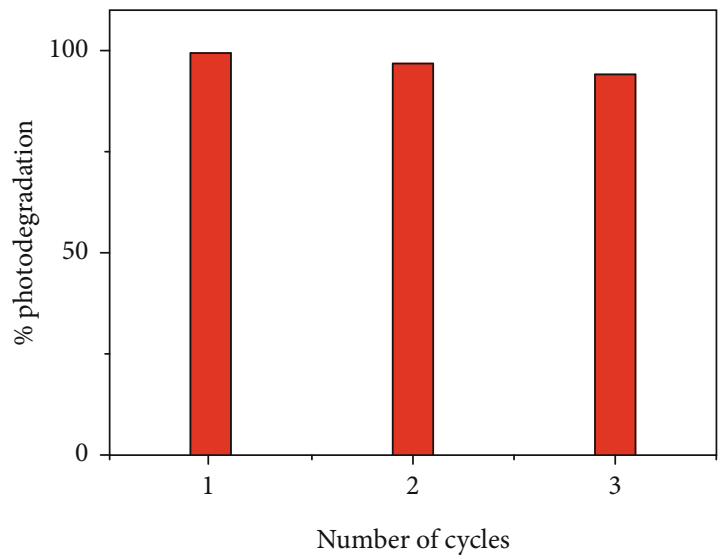

Figure 9: $\mathrm{ZnO}$ nanoparticle $(\mathrm{ZnO}-750)$ catalyst reusability degradation efficiency vs. cycle numbers under UV light irradiation 0 to 40 minutes.

process of $\mathrm{ZnO}-450, \mathrm{ZnO}-550, \mathrm{ZnO}-650$, and $\mathrm{ZnO}-750$ are $0.0512,0.0636,0.1077$, and $0.1286 \mathrm{~min}^{-1}$, respectively.

\section{Data Availability}

The data used to support the findings are available from the corresponding author upon request.

\section{Conflicts of Interest}

The authors declare that they have no conflicts of interest.

\section{Acknowledgments}

This study was supported by the Ministry of Science and Technology in South Korea through the International Environmental Research Institute (IERI) of Gwangju Institute of Science and Technology (GIST) in 2019.

\section{References}

[1] L. Bilińska, M. Gmurek, and S. Ledakowicz, "Textile wastewater treatment by AOPs for brine reuse," Process Safety and Environmental Protection, vol. 109, pp. 420-428, 2017.

[2] R. M. Christie, Environmental Aspects of Textile Dyeing, Woodhead Publishing Limited, 2007.

[3] S. K. Sharma, Green Chemistry for Dyes Removal from Wastewater: Research Trends and Applications, Scrivener Publishing, John Wiley \& Sons, 2015.

[4] K. Qi, B. Cheng, J. Yu, and W. Ho, "Review on the improvement of the photocatalytic and antibacterial activities of ZnO," Journal of Alloys and Compounds, vol. 727, pp. 792820, 2017.

[5] H. Liu, L. Li, C. Guo, J. Ning, Y. Zhong, and Y. Hu, "Thicknessdependent carrier separation in $\mathrm{Bi} 2 \mathrm{Fe} 4 \mathrm{O} 9$ nanoplates with enhanced photocatalytic water oxidation," Chemical Engineering Journal, vol. 385, article 123929, 2020.

[6] R. Peña-Garcia, Y. Guerra, B. V. M. Farias, D. M. Buitrago, A. Franco Jr., and E. Padrón-Hernández, "Effects of temperature and atomic disorder on the magnetic phase transitions in $\mathrm{ZnO}$ nanoparticles obtained by sol-gel method," Materials Letters, vol. 233, pp. 146-148, 2018.

[7] D. Sharma, S. Sharma, B. S. Kaith, J. Rajput, and M. Kaur, "Synthesis of $\mathrm{ZnO}$ nanoparticles using surfactant free in-air and microwave method," Applied Surface Science, vol. 257, no. 22, pp. 9661-9672, 2011.

[8] R. O. Yathisha, Y. A. Nayaka, and C. C. Vidyasagar, "Microwave combustion synthesis of hexagonal prism shaped $\mathrm{ZnO}$ nanoparticles and effect of $\mathrm{Cr}$ on structural, optical and electrical properties of $\mathrm{ZnO}$ nanoparticles," Materials Chemistry and Physics, vol. 181, pp. 167-175, 2016.

[9] M. Y. Nassar, M. M. Moustafa, and M. M. Taha, "Hydrothermal tuning of the morphology and particle size of hydrozincite nanoparticles using different counterions to produce nanosized $\mathrm{ZnO}$ as an efficient adsorbent for textile dye removal," RSC Advances, vol. 6, no. 48, pp. 42180-42195, 2016.

[10] N. Kumaresan, K. Ramamurthi, R. Ramesh Babu, K. Sethuraman, and S. Moorthy Babu, "Hydrothermally grown $\mathrm{ZnO}$ nanoparticles for effective photocatalytic activity," Applied Surface Science, vol. 418, pp. 138-146, 2017.

[11] A. P. A. Oliveira, J.-F. Hochepied, F. Grillon, and M.-H. Berger, "Controlled precipitation of zinc oxide particles at room temperature," Chemistry of Materials, vol. 15, no. 16, pp. 32023207, 2003.

[12] M. Kahouli, A. Barhoumi, A. Bouzid, A. al-Hajry, and S. Guermazi, "Structural and optical properties of $\mathrm{ZnO}$ nanoparticles prepared by direct precipitation method," Superlattices and Microstructures, vol. 85, pp. 7-23, 2015.

[13] Udayabhanu, G. Nagaraju, H. Nagabhushana et al., "Green, nonchemical route for the synthesis of $\mathrm{ZnO}$ superstructures, evaluation of its applications toward photocatalysis, photoluminescence, and biosensing," Crystal Growth \& Design, vol. 16, no. 12, pp. 6828-6840, 2016. 
[14] S. Baskoutas, P. Giabouranis, S. N. Yannopoulos et al., "Preparation of $\mathrm{ZnO}$ nanoparticles by thermal decomposition of zinc alginate," Thin Solid Films, vol. 515, no. 24, pp. 8461$8464,2007$.

[15] C.-C. Lin and Y.-Y. Li, "Synthesis of $\mathrm{ZnO}$ nanowires by thermal decomposition of zinc acetate dihydrate," Materials Chemistry and Physics, vol. 113, no. 1, pp. 334-337, 2009.

[16] S. Labuayai, V. Promarak, and S. Maensiri, "Synthesis and optical properties of nanocrystalline $\mathrm{ZnO}$ powders prepared by a direct thermal decomposition route," Applied Physics A, vol. 94, no. 4, pp. 755-761, 2009.

[17] R. Shankar, R. K. Srivastava, and S. G. Prakash, "ZnO NPs synthesized by thermal decomposition of zinc oxalate at $300^{\circ} \mathrm{C}$ and its photo response under UV-illumination," in AIP Conference Proceedings, p. 239, Bikaner, Rajasthan, India, 2013.

[18] M. I. Khalil, M. M. Al-Qunaibit, A. M. Al-zahem, and J. P. Labis, "Synthesis and characterization of $\mathrm{ZnO}$ nanoparticles by thermal decomposition of a curcumin zinc complex," Arabian Journal of Chemistry, vol. 7, no. 6, pp. 1178-1184, 2014.

[19] N. N. Kumaran and K. Muraleedharan, "Photocatalytic activity of $\mathrm{ZnO}$ and $\mathrm{Sr}^{2+}$ doped $\mathrm{ZnO}$ nanoparticles," Journal of Water Process Engineering, vol. 17, pp. 264-270, 2017.

[20] Joint Committee for Powder Diffraction Society (JCPDS), "Powder Diffraction Database," Pattern, 36-1451.

[21] W. Zhou, F. Sun, K. Pan et al., "Well-ordered large-pore mesoporous anatase $\mathrm{TiO}_{2}$ with remarkably high thermal stability and improved crystallinity: preparation, characterization, and photocatalytic performance," Advanced Functional Materials, vol. 21, no. 10, pp. 1922-1930, 2011.

[22] G. Tian, H. Fu, L. Jing, B. Xin, and K. Pan, "Preparation and characterization of stable Biphase $\mathrm{TiO} 2$ Photocatalyst with high crystallinity, large surface area, and enhanced photoactivity," Journal of Physical Chemistry C, vol. 112, no. 8, pp. 30833089, 2008.

[23] R. Saravanan, V. K. Gupta, V. Narayanan, and A. Stephen, "Comparative study on photocatalytic activity of $\mathrm{ZnO}$ prepared by different methods," Journal of Molecular Liquids, vol. 181, pp. 133-141, 2013.

[24] W. Yang, L. Zhang, Y. Hu, Y. Zhong, H. B. Wu, and X. W. D. Lou, "Microwave-assisted synthesis of porous $\mathrm{Ag}_{2} \mathrm{~S}-\mathrm{Ag}$ hybrid nanotubes with high visible-light photocatalytic activity," Angewandte Chemie International Edition, vol. 51, no. 46, pp. 11501-11504, 2012.

[25] Y. Wang, W. Yang, L. Zhang, Y. Hu, and X. W. (David) Lou, "Formation of MS-Ag and MS ( $\mathrm{M}=\mathrm{Pb}, \mathrm{Cd}, \mathrm{Zn})$ nanotubes via microwave-assisted cation exchange and their enhanced photocatalytic activities," Nanoscale, vol. 5, no. 22, pp. 10864-10867, 2013.

[26] A. Balcha, O. P. Yadav, and T. Dey, "Photocatalytic degradation of methylene blue dye by zinc oxide nanoparticles obtained from precipitation and sol-gel methods," Environmental Science and Pollution Research, vol. 23, no. 24, pp. 25485-25493, 2016.

[27] C. Yang, Q. Li, L. Tang, A. Bai, H. Song, and Y. Yu, "Monodispersed colloidal zinc oxide nanospheres with various size scales: synthesis, formation mechanism and enhanced photocatalytic activity," Journal of Materials Science, vol. 51, no. 11, pp. 5445-5459, 2016.

[28] E. Prabakaran and K. Pillay, "Synthesis of N-doped ZnO nanoparticles with cabbage morphology as a catalyst for the efficient photocatalytic degradation of methylene blue under UV and visible light," RSC Advances, vol. 9, no. 13, pp. 7509-7535, 2019.

[29] L. Li, C. Guo, J. Shen, J. Ning, Y. Zhong, and Y. Hu, "Construction of sugar-gourd-shaped CdS/Co1-xS hollow heteronanostructure as an efficient Z-scheme photocatalyst for hydrogen generation," Chemical Engineering Journal, vol. 400, article 125925,2020

[30] H. Zhang, C. Guo, J. Ren et al., "Beyond $\mathrm{CoO}_{\mathrm{x}}$ : a versatile amorphous cobalt species as an efficient cocatalyst for visible-light-driven photocatalytic water oxidation," Chemical Communications, vol. 55, no. 93, pp. 14050-14053, 2019. 